\title{
ANALISIS KINERJA DIREKTORAT JENDRAL PAJAK DALAM OPTIMALISASI PENERIMAAN PAJAK DI ERA-PANDEMI COVID-19
}

Oleh:

\author{
Lutfia Rizkyatul Akbar \\ Program Studi Pendidikan Ekonomi \\ Fakultas Ilmu Pendidikan dan Pengetahuan Sosial \\ Universitas Indraprasta PGRI
}

Email:

Lutfiarizkyatul@gmail.com

\begin{abstract}
ABSTRAK
Peneliti ingin menganalisis apa saja tantangan yang sedang dan akan dihadapi dalam penerimaan pajak dan bagaimana cara Direktorat Jendral Pajak dalam optimalisasi penerimaan pajak di era pandemi Covid-19. Penelitian menggunakan pendekatan kualitatif dengan teknik pengumpulan data diperoleh peneliti dari data sekunder yang berhubungan dengan tema penelitian yang didapatkan dari data resmi Direktorat Jendral Pajak, Kementrian Keuangan, dan data sekunder lainnya. Hasil penelitian ini adalah kinerja DJP masih rendah yang tergambar dari penerimaan pajak di negara Indonesia selama lima tahun belum mampu mencapai target, kepatuhan pajak yang diukur melalui pelaporan SPT Tahunan juga masih jauh dari target, serta tax ratio yang selama lima tahun terakhir cenderung diangka yang sama dan tidak megalami peningkatan. Beberapa strategi DJP dalam optimalsiasi penerimaan pajak adalah sebagai berikut Pertama, Ekstensifikasi pemerintah harus segera menerapkan pajak digital di era pandemi Covid-19 ini. Kedua, Pajak Bandara Bebas untuk Memulihkan Sektor Pariwisata. Ketiga, pemberian insentif pajak.
\end{abstract}

Kata Kunci: optimalsiasi penerimaan pajak, pandemi Covid-19 


\begin{abstract}
This research aims to analyze what are the challenges currently and will be faced in tax revenue and how the Directorate General of Taxes in optimizing tax revenue during the Covid-19 Pandemic. The study used a qualitative approach with data collection techniques obtained by the author from secondary data related to the research theme obtained from official data from the Directorate General of Taxes, Ministry of Finance, and other secondary data. The results of this study are the performance of the DGT is still low as reflected in the tax revenue in Indonesia which for 5 years has not been able to reach the target, tax compliance as measured by the annual SPT reporting is also still far from the target and the tax ratio which for the last 5 years tends to be calculated the same and not increasing. Some of the DGT's strategies in optimizing tax revenue are as follows: First, government expansion must immediately implement digital taxes in the era of the Covid-19 pandemic. Second, Free Airport Tax to Restore the Tourism Sector. Third, providing tax incentives.
\end{abstract}

Keywords: optimization of tax revenue, Covid-19 pandemic

\title{
A. PENDAHULUAN
}

Pandemi Covid-19 yang tengah terjadi di seluruh dunia menjadi tantangan ketahanan ekonomi, tak terkecuali di Indonesia. Berubahnya tatanan perekonomian negara juga mengakibatkan berubahnya kinerja suatu instansi, tak terkecuali Direktorat Jendral Pajak sebagai lembaga pemungut pajak negara. Sudah delapan bulan sejak hadirnya wabah virus Covid-19 membuat berbagai sektor usaha mengalami kerugian, kinerja fiskus juga menjadi terbatas dengan adanya work from home. Penerimaan pajak yang masih menjadi tulang punggung perekonomian dan berkontribusi besar terhadap APBN juga turut terkena dampaknya. Berikut tabel penerimaan pajak di Indonesia:

Tabel 1.

Penerimaan Pajak di Indonesia Tahun 2016-2020

Presentase Realisasi Penerimaan Pajak (dalam triliun rupiah)

\begin{tabular}{cccccc}
\hline Tahun & $\mathbf{2 0 1 6}$ & $\mathbf{2 0 1 7}$ & $\mathbf{2 0 1 8}$ & $\mathbf{2 0 1 9}$ & $\mathbf{2 0 2 0}$ \\
\hline Target & $1.355,20$ & $1.283,60$ & 1.424 & $1.577,60$ & $1.198,82$ \\
Realisasi & $1.105,97$ & $1.151,03$ & $1.313,33$ & $1.332,60$ & 720,62 \\
Capaian & $82 \%$ & $90 \%$ & $92 \%$ & $84 \%$ & $62,61 \%$ \\
\hline \multicolumn{5}{c}{ *Penerimaan 2020 masih Januari-September 2020} \\
Sumber : (DDTC, 2020b)
\end{tabular}

Berdasarkan tabel 1 di atas menggambarkan bahwa penerimaan pajak tahun 2020 masih jauh dari target yaitu 62,61\% di bulan September 2020. Data realisiasi semester $1 / 2020$, rasio kepatuhan formal wajib pajak badan masih rendah yaitu 11,46juta dari 19 juta wajib pajak yang menyampaikan SPT Tahunan (DDTC, 2020a). Pandemi Covid-19 memberi dampak yang cukup signifikan dalam penurunan penerimaan pajak di Indonesia. 
Salah satu penerimaan negara yang terbesar yaitu pajak sedang mengalami hambatan, maka opsi pemerintah yang lain adalah utang. Utang luar negeri Indonesia tercatat sebesar US\$ 409,7 miliar pada bulan juli 2020. Angka itu setara dengan Rp 6.003 triliun rupiah. Hal ini tergambar dalam tabel di bawah ini:

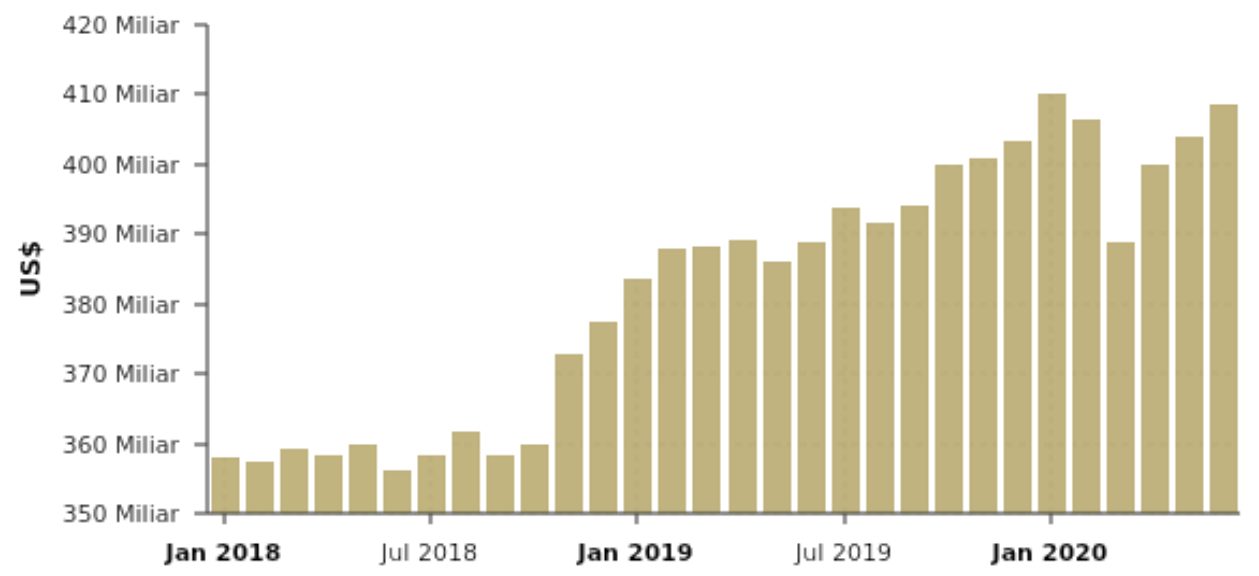

Sumber: (Data, 2020)

\section{Gambar 1.} Utang Indonesia

Berdasarkan Gambar 1 tergambar bahwa utang luar negeri negara Indonesia selama tiga tahun terakhir mengalami kenaikan yang sangat signifikan. Utang merupakan pinjaman yang dilakukan oleh suatu negara karena pembiayaan atau belanjanya lebih banyak daripada penerimaannya. Sehingga utang merupakan langkah yang ditempuh karena sumber penerimaan tidak mencukupi atau rendah.

Direktur Potensi, Kepatuhan, dan Penerimaan Pajak DJP Ihsan Priyawibawa yang dikutip dari (Putra, 2020) mengatakan bahwa tantangan yang dihadapi oleh DJP dalam penerimaan pajak adalah meliputi turunnya tarif pajak penghasilan atau PPh Badan yang berawal dari tarif sebesar 25 persen menjadi tarif 22 persen, harga komoditas yang cukup rendah, perubahan struktur perekonomian negara dan adanya perkembangan transaksi elektronik pula menjadi tantangan dalam meningkatkan penerimaan negara, dunia usaha (pelaku usaha) terdampak Covid-19 yang menyebabkan pelaku usaha mengalami kerugian, ekstensifikasi dan intensifikasi pajak yang terhambat sehingga menyebabkan kepatuhan pajak belum optimal karena bekerja dari rumah (work from home).

Tax ratio menjadi tolak ukur atau patokan dasar kinerja otoritas pajak dibanyak negara di seluruh dunia. Tax ratio menggambarkan baik dan tidaknya otoritas perpajakan dalam memungut pajak di suatu negara. Indonesia tergolong ke dalam lower middle income countries yang berarti kepatuhan pajaknya masih rendah. Tax ratio menggambarkan bahwa kemampuan otoritas pajak atau fiskus dalam mencari peluang dan menggali potensi wajib pajak untuk meningkatkan penerimaan pajak belum optimal. Kondisi ekonomi yang merosot, penerimaan pajak yang jauh dari target penerimaan pajak, tax ratio yang tertinggal dari negara- 
negara tetangga, serta adanya pandemi Covid-19 ini, peneliti ingin menganalisis apa saja tantangan yang sedang dan akan dihadapi dalam penerimaan pajak dan apa strategi Direktorat Jendral Pajak dalam optimalisasi penerimaan pajak dikala Pandemi Covid-19.

\section{B. KAJIAN LITERATUR}

\section{Analisis Kinerja}

Kinerja yang disampaikan Bernadin dan Russel yang dikutip oleh (Triadi, 2013) adalah outcome yang dihasilkan dari fungsi suatu pekerjaan tertentu atau kegiatan selama periode tertentu. Kinerja juga didefinisikan sebagai hasil dari pekerjaan yang terkait dengan tujuan organisasi seperti kualitas, kriteria efektivitas, dan efisiensi. Hasil yang didapat oleh seseorang maupun organsisasi dengan mengacu tujuan suatu organisasi dapat diartikan pula sebagai kinerja. Kinerja juga dapat dilihat atau diukur dari kuantitas dan kualitas outcome, serta goals. Mahsun yang dikutip oleh (Lasfika, 2020) mengemukakan bahwa kinerja adalah gambaran mengenai tingkat pencapaian pelaksanaan suatu kegiatan/ program. Kebijakan dalam mewujudkan sasaran, tujuan, misi, dan visi organisasi yang tertuang dalam mewujudkan planning suatu organisasi. Analisis kinerja diperlukan untuk melihat seberapakah realisasi yang sudah dicapai dari target atau tujuan suatu organisasi. Dalam penelitian ini tentang optimalisasi penerimaan pajak dikala pandemi Covid19, sehingga peneliti ingin menganalisis bagaimana kinerja pemungut pajak yaitu Direktorat Jendral Pajak. Kinerja yang disampaikan oleh Bernadin dan Russel menjadi pedoman peneliti dengan melihat kualitas, kriteria efektivitas, efisiensi, serta seberapa pencapaian DJP dalam penerimaan pajaknya.

\section{Administrasi dan Kebijakan Pajak}

Administrasi pajak adalah lembaga yang menangani dan yang bertanggung jawab terhadap pemungutan pajak di suatu negara. Menurut Mansury sebagaimana dikutip oleh (Rosdiana Haula, 2012) mengatakan bahwa administrasi pajak adalah suatu instansi yang mempunyai wewenang dan tanggungjawab untuk penyelenggaraan pemungutan pajak di Indonesia, orang-orang yang terdiri dari pejabat dan pegawai yang bekerja pada suatu instansi perpajakan melaksanakan kegiatan pemungutan pajak, serta proses kegiatan penyelenggaraan pemungutan pajak yang baik, sehingga mampu mencapai target dan sasaran yang telah ditentukan dalam kebijakan perpajakan dan berdasarkan sarana hukum yang ditentukan oleh undang-undang perpajakan secara efisien.

The Doha Declaration yang dikutip oleh (Kommer, 2011) juga menyampaikan terdapat empat elemen untuk meningkatkan sistem pajak di negaranegara berkembang: Increasing tax revenue by modernizing tax system (Meningkatkan penerimaan pajak dengan memodernisasi sistem perpajakan), Improving the effectiveness and efficiency of tax collection (Meningkatkan efektivitas dan efisiensi pengumpulan pajak), Broadening of tax base (Perluasan basis pajak), Effectively combating tax evasion (Melawan penggelapan pajak). Sumber daya manusia (SDM) juga menjadi tolak ukur suatu kinerja administrasi pajak. Administrasi pajak memegang peranan penting karena tidak hanya berfungsi 
sebagai perangkat laws enforcement, tetapi juga service point yang memberikan pelayanan prima dan pusat informasi kepada masyarakat.

Kebijakan yang disampaikan oleh Thomas R. Dye yang dikutip oleh (Kamilia et al., 2014) adalah apa pun yang pemerintah pilih untuk dilakukan ataupun tidak dilakukan dengan tujuan untuk mengorganisasikan konflik yang terdapat dalam masyarakat sehingga tercipta hasil yang membuat kehidupan tampil berbeda dari sebelumnya. Pajak menurut Mansury yang dikutip oleh (Rosdiana Haula, 2012) bahwa kebijakan pajak dalah kebijakan yang berhubungan dengan penentuan tax base, penentuan subjek pajak, penentuan subjek pajak yang dikecualikan, penentuan objek pajak dan pengecualian objek pajak, serta penentuan besarnya pajak yang terutang, dan bagaimana menentukan prosedur pelaksanaan kewajiban yang terutang. Teori administrasi dan kebijakan pajak yang dikemukakan di atas dapat membantu peneliti menganalisis bahwa Direktorat Jendral Pajak sebagai Administrator pajak bertugas untuk meningkatkan penerimaan yang berfungsi sebagai law enforcement dan service point kepada masyarakat. DJP juga bertugas sebagai pembuat kebijakan pajak yang diharapkan dapat menunjang penerimaan negara dan menstabilkan ekonomi dikala pandemi Covid-19.

\section{Fungsi Negara dan Pajak}

Negara memiliki beberapa fungsi yaitu fungsi alokasi, distribusi, stabilisasi, dan regulasi. Adanya pandemi Covid-19 menyebabkan berbagai permasalahan perekonomian yang berdampak pada penerimaan pajak. Negara hadir dengan menjalankan berbagai fungsinya yaitu stabilisasi dan regulasi. Menurut Musgrave yang dikutip (Rosdiana Haula, 2012) fungsi stabilisasi dapat dilakukan dengan menggunakan kebijakan anggaran sebagai alat untuk menjaga agar tingkat tenaga kerja tetap tinggi, tingkat stabilitas harga pasar layak, pertumbuhan ekonomi yang tepat, dengan mempertimbangkan dampaknya bagi perdagangan dan keseimbangan pembayaran.

Berbagai macam fungsi pajak, salah satunya adalah pembangunan ekonomi (Rosdiana Haula, 2012) mengatakan bahwa pajak dapat dijadikan sebagai instrumen untuk mendistorsi aktivitas ekonomi tertentu yang tidak diharapkan pemerintah. Pilihan untuk memilih antara insentif ataupun disinsentif selaras dengan penentuan pemerintah mana sektor yang harus dikembangkan dan sebaliknya. Kebijakan insentif harus didesain dengan program pemmbanguanan ekonomi nasional. Berdasarkan deskripsi dari fungsi negara dan pajak dapat ditarik kesimpulan bahwa pajak dan negara tidak dapat dipisahkan satu sama lain, negara harus hadir dengan berbagai kebijakan yang tepat dalam penanganan ekonomi bangsa melalui kebijakan pajak.

Penerimaan pajak berdasarkan penelitian Hutagaol yang dikutip dari (Desideria, 2019) bahwa sumber penerimaan yang dapat diperoleh secara terusmenerus dan dapat dikembangan secara optimal sesuai dengan kebutuhan pemerintah dan kondisi masyarakat. Negara harus hadir untuk menyelesaikan permasalahan ekonomi di tengah masyarakat. Pajak dan negara menjadi satu kesatuan memberi solusi, sehingga penerimaan pajak dapat optimal. Penerimaan pajak menjadi tulang punggung perekonomian negara, mengakibatkan DJP mempunyai tugas yang cukup besar dalam menjalankan perannya. 


\section{Optimalisasi Penerimaan Pajak}

Optimilalisasi penerimaan pajak di tengah pandemi Covid-19 menjadi tantangan oleh negara, namun negara harus tetap menjalankan fungsinya sebagai pembuat stabilisasi dan regulasi. Pengumpulan pajak juga membutuhkan cost of collection, mengutip (Cheisviyanny, 2020) terdapat biaya pengumpulan pajak yaitu meliputi biaya gaji pegawai pajak, biaya penyelenggaraan pemeriksaan, sengket apajak, biaya pengadaan dan perawatan IT, baya pelaksanaan program perpajakan. Optimalisasi penerimaan pajak adalah suatu usaha yang dilakukan oleh pemerintah untuk membuat penerimaan pajak menjadi lebih baik dari segi kualitas dan kuantitas. Optimalisasi penerimaan pajak menurut Nurmantu yang dikutip oleh (Valensky, 2018) memiliki beberapa faktor yang menentukan keberhasilan yaitu kejelasan undang-undang perpajakan, tingkat pendidikan wajib pajak, kualitas dan kuantitas petugas pajak, strategi pengadministrasian pajak dalam organisasi. terpenuhi jika seluruh wajib pajak memenuhi kewajiban perpajakannya, seluruh objek pajak milik wajib pajak dilaporkan seluruhnya kepada fiskus, seluruh objek pajak tidak terlepas dai pengamatan, pemeriksaan, dan hitungan fiskus.

Dalam penelitian ini, peneliti ingin menganalisis apakah penerimaan pajak dapat optimal dikala pandemi Covid-19. Optimal digambarkan sebagai keberhasilan dari segi kualitas dan kuantitas. Sehingga peneliti akan menganalisis data penerimaan pajak (segi kuantitas) dan data kepatuhan wajib pajak dalam pelaporan Surat Pemberitahuan (SPT) yang dianalisis dari segi kualitas. Analisis kinerja DJP dalam optimalisasi penerimaan pajak Covid-19 dapat dilakukan dengan melihat realisasi dari target penerimaan pajak di Indonesia, dan apa saja strategi yang dilakukan oleh DJP dalam mengoptimalkan penerimaan dikala pandemi.

\section{METODE PENELITIAN}

Penelitian ini menggunakan pendekatan kualitatif. Menurut Cresswell yang dikutip oleh (Hafidz Al Faruqi, 2016), peneliti adalah instrumen utama penelitian, mencakup penelitian lapangan, peneliti menekankan sikap deskriptif, prosesnya bersifat induktif sehingga peneliti membangun abstraksi dan konsep detail yang diperoleh dari penelitannya. Teknik analisis data kualitatif meliputi reduksi data, penyajian data, dan penarikan kesimpulan. Peneliti mengguankan tipe data time series dimana peneliti menggunakan satu objek namun terdiri dari beberapa waktu periode tahunan. Penelitian menggunakan teknik pengumpulan data yang diperoleh penulis dari data sekunder yang berhubungan dengan tema penelitian yang didapatkan dari data resmi Direktorat Jendral Pajak, Kementrian Keuangan, dan data sekunder lainnya. Data sekunder berupa data penerimaan pajak di Indonesia Tahun 2016-2020, data utang di Indonesia, data kepatuhan wajib pajak tahun 20142018, tax ratio Indonesia tahun 2015-2019.

\section{HASIL DAN PEMBAHASAN}

\section{Analisis Kinerja DJP dalam Penerimaan Pajak}

Analisis kinerja Direktorat Jendral Pajak dalam penerimaan pajak di tengah pandemi Covid-19 yang mulai terjadi di Indonesia pada bulan Maret Tahun 2020. Pandemi Covid-19 telah merubah tatanan perekonomian, mengubah strategi 
pemerintah dalam penerimaan pajak. Target dari penerimaan pajak juga telah diturunkan sebagai dampak dari pandemi ini. Realisasi penerimaan yang mulanya setiap tahun meningkat, ditahun pandemi ini juga dikhawatirkan akan menurun. Hal ini diakibatkan para pelaku usaha yang menjadi subjek pajak telah banyak terdampak. Hal ini menjadi concern dan perhatian peneliti bagaimana kinerja pemungut pajak di Indonesia dalam hal ini yaitu Direktorat Jendral pajak. Kinerja menurut Bernadin dan Russel yang dikutip oleh (Triadi, 2013) adalah outcome yang dihasilkan dari fungsi suatu pekerjaan tertentu atau kegiatan selama periode tertentu. Outcome dari pemungut pajak dalam menilai keberhasilan kinerja secara tidak langsung digambarkan dengan realisasi penerimaan pajaknya. Fungsi pajak yang paling utama adalah sumber pendapatan negara. Ini terbukti di negara Indonesia, pajak menyumbang 720,62 triliun rupiah hingga bulan September tahun 2020. Sumbangan tersebut menjadi sumbangan penerimaan terbesar dari seluruh penerimaan negara lainnya. Penerimaan pajak juga terus meningkat dari tahun ke tahun. Berikut hasil dari kinerja DJP dalam optimalisasi penerimaan pajak, berikut tabelnya:

\section{Tabel 2.}

\section{Penerimaan Pajak di Indonesia Tahun 2016-2020}

Presentase Realisasi Penerimaan Pajak (dalam triliun rupiah)

\begin{tabular}{cccccc}
\hline Tahun & $\mathbf{2 0 1 6}$ & $\mathbf{2 0 1 7}$ & $\mathbf{2 0 1 8}$ & $\mathbf{2 0 1 9}$ & $\mathbf{2 0 2 0} *$ \\
\hline Target & $1.355,20$ & $1.283,60$ & 1.424 & $1.577,60$ & $1.198,82$ \\
Realisasi & $1.105,97$ & $1.151,03$ & $1.313,33$ & $1.332,60$ & 720,62 \\
Capaian & $82 \%$ & $90 \%$ & $92 \%$ & $84 \%$ & $62,61 \%$ \\
\hline \multicolumn{5}{c}{ (Denerimaan 2020 masih Januari-September 2020 } \\
(DDTC, 2020b)
\end{tabular}

Berdasarkan Tabel 2 di atas diketahui bahwa penerimaan pajak selama lima tahun belum mencapai target. Jika dikaitkan dengan kinerja suatu organisasi maka dengan tidak tercapainya realisasi atas target yang ada, kinerja DJP masih belum baik. Sejalan dengan target yang masih jauh dari target, kepatuhan wajib pajak di Indonesia juga masih tergolong rendah. Sumber perpajakan dinilai aman, karena derajat kemandirian negara paling tinggi dan terhindar dari intervensi-intervensi negara lain atau lembaga-lembaga pemberi pinjaman. Sedangkan yang dimaksud pajak itu murah adalah suatu negara tidak dibebani dengan kewajiban membayar bunga sebagaimana kewajiban pada obligasi. Dan pajak itu sumber berkelanjutan berarti sumber sumber pemungutan pajak berada pada setiap aktivitas masyarakat.

Nurmantu sebagaimana dikutip oleh (Rahayu, 2010) mengemukakan bahwa kepatuhan pajak dideskripsikan sebagai keadaan-keadaan dimana wajib pajak dapat memenuhi semua kewajiban perpajakannya. Kepatuhan pajak dapat diartikan melalui beberapa hal yaitu kepatuhan wajib pajak untuk mendaftarkan diri, kepatuhan untuk menyetor kembali surat pemberitahuan (SPT), kepatuhan dalam penghitungan dan pembayaran pajak terutang, serta kepatuhan wajib pajak dalam pembayaran tunggakan pajak. Kepatuhan pajak di Indonesia dari tahun ketahun juga mengalami trend kenaikan dari segi jumlah kepatuhan pembayaran pajak, namun dari pembanding jumlah total wajib pajak tetap tergolong sangat rendah. Penerimaan pajak sangat bergantung dari kepatuhan pajak masyarakat, jika 
kepatuhannya membaik, maka penerimaan juga akan megalami kenaikan. Berikut data kepatuhan pajak yang ada di Indonesia:

Tabel 3.

Data Kepatuhan SPT Tahunan 2014 hingga 2018

\begin{tabular}{lrrrrr}
\hline & \multicolumn{5}{c}{ Tahun } \\
\cline { 2 - 6 } Jenis Wajib Pajak & $\mathbf{2 0 1 4}$ & $\mathbf{2 0 1 5}$ & $\mathbf{2 0 1 6}$ & $\mathbf{2 0 1 7}$ & \multicolumn{1}{c}{$\begin{array}{c}\mathbf{2 0 1 8} \\
\text { (per 13/12/2018) }\end{array}$} \\
\hline Badan & 552,740 & 681,488 & 706,798 & 774,188 & 845,683 \\
OP Non Karyawan & 641,923 & 846,086 & 935,055 & $1,208,723$ & $1,775,937$ \\
OP Karyawan & $9,657,686$ & $9,445,376$ & $10,607,940$ & $10,065,056$ & $9,841,286$ \\
Total & $10,852,349$ & $10,972,950$ & $12,249,793$ & $12,047,967$ & $12,462,906$ \\
\hline & \multicolumn{5}{c}{ Sumber: (Pajak, 2018) }
\end{tabular}

Berdasarkan dari dua tabel yaitu penerimaan pajak dan data kepatuhan pelaporan SPT di atas bahwa sama-sama mengalami trend kenaikan. Penerimaan pajak meningkat dan jumlah wajib pajak yang melaporkan SPT juga meningkat. Di tahun 2020 Wajib Pajak terdaftar sekitar 19 juta wajib pajak, dan yang sudah melapor adalah 11,5 juta wajib pajak. Angka tersebut jika dipersentasekan adalah sebesar $60,34 \%$ jumlah wajib pajak yang taat pajak. Angka tersebut tergolong rendah dan kepatuhan wajib pajak dikategorikan rendah.

Realisasi penerimaan pajak yang jauh dari target, kepatuhan pajak yang masih tergolong rendah, tergambar pada tax ratio Indonesia yang selama lima tahun masih diangka yang sama dan tidak ada peningkatan kecuali di tahun 2018. Hal ini dapat diketahui dari tabel berikut ini:

Tabel 4.

Tax ratio Tahun 2015-2019 di Indonesia

\begin{tabular}{cc}
\hline Tahun & Realisasi \\
\hline 2015 & $10,7 \%$ \\
2016 & $10,3 \%$ \\
2017 & $10,9 \%$ \\
2018 & $11,5 \%$ \\
2019 & $10,7 \%$ \\
\hline \multicolumn{2}{c}{ Sumber: Dioleh Peneliti (2020) }
\end{tabular}

Sumber: Dioleh Peneliti (2020)

Berdasarkan tabel 4 tax ratio di atas dapat tergambar bahwa kinerja otoritas pajak sebagai pemungut pajak masih rendah. Penerimaan perpajakan di Indonesia yang selama lima tahun belum mampu mencapai target, kepatuhan pajak yang diukur melalui pelaporan SPT Tahunan juga belum dapat mencapai target yang seharusnya, tax ratio yang selama lima tahun terakhir cenderung diangka yang sama dan tidak megalami peningkatan. Tax ratio yang rendah juga dapat menggambarkan penerimaan pajak di Indonesia masih jauh dari target dan kepatuhan pajaknya juga masih tergolong sangat rendah. Hal ini dapat diketahui 
bahwa kinerja DJP ebagai pemungut pajak dalam meningkatkan penerimaan pajak harus ditingkatkan dan membutuhkan strategi dalam mengoptimalkannya.

\section{Strategi Kinerja DJP dalam Optimalisasi Penerimaan Pajak di Era Pandemi Covid-19}

Kinerja penerimaan pajak sudah dipaparkan di atas dengan menggambarkan tabel penerimaan dan tax ratio. Penerimaan pajak di tahun 2020 hingga bulan September masih sangat rendah. Pandemi Covid-19 telah menjadi hambatan dan tantangan dari perekonomian negara Indonesia. DJP sebagai pemungut pajak merupakan instansi yang bertugas dan bertanggung jawab dalam pemungutan pajak. Mengingat pajak adalah penyumbang terbesar APBN negara ini, maka langkah optimalisasi penerimaan harus menjadi fokusan agar keuangan negara dapat stabil dan baik. Mengutip dari (Rosdiana \& Irianto, 2012), unsur-unsur yang ada dalam definisi pajak terdiri dari, pemungutan pajak dapat dipaksakan, pajak dipungut berdasarkan undang-undang, tidak mendapat imbalan langsung, dan pajak digunakan untuk menjalankan fungsi negara. Unsur-unsur tersebut ada dalam pemungutan pajak, namun pada akhirnya pajak berfungsi untuk negara yang bertujuan bagi sebesarbesarnya kemakmuran rakyat.

Indonesia merupakan negara demokrasi yang dalam pemungutan pajaknya harus bersifat adil bagi seluruh lapisan masyarakat.(Rosdiana \& Irianto, 2012) menjelaskan bahwa gagasan demokratisasi perpajakan menjadi penting untuk dikembangkan karena berberapa alasan. Pertama, semakin terbukanya iklim politik di Indonesia dan perkembangan pasar bebas. Kedua, meningkatnya kesadaran suatu masyarakat dalam kewajiban perpajakan sehingga meningkatnya tuntutan transparasi dalam pengelolaan pajak oleh pemungut pajak. Ketiga, menguatnya sistem ekonomi yang demokratis. Berdasarkan dari paparan di atas dapat diketahui bahwa dalam pelaksanaan demokrasi perpajakan membutuhkan keterlibatan dan partisipasi masyarakat sebagai pendukung kebijakan pemerintah sebagai kewajiban dalam membayarkan pajaknya.

Beberapa strategi DJP dalam optimalsiasi penerimaan pajak adalah sebagai berikut: Pertama, Ekstensifikasi. Berbagai masalah penerimaan pajak menghambat perekonomian negara, hal ini harus mendorong usaha pemerintah untuk mencari sumber baru atau objek baru. E-commerce yang saat ini tengah mengalami kenaikan trend di dunia, terlebih adanya pandemi Covid-19 yang mendorong masyarakat untuk bekerja dari rumah, beraktivitas di rumah, berbelanja dari rumah. Beberapa tahun terakhir, pemerintah belum dapat menangkap dan belum memiliki strategi yang tepat untuk menangkap peluang penerimaan pajak di sektor digital ini. Pemerintah menerbitkan Peraturan Menteri Keuangan dengan Nomor 48/PML.03/2020 tentang Pengenaan PPN atas Perdagangan Melalui Sistem Elektronik atau PMSE yang merupakan turunan Undang-undang Nomor 2 tahun 2020. Melalui PMK ini DJP akan dapat memungut PPN PMSE yang selama ini tidak dapat memungut walaupun bertransaksi di Indonesia. Beberapa platform yang sudah ditunjuk oleh DJP sebagai pemungut pajak adalah Amazon, Google, Netflix, Spotivy, Facebook, Tiktok, Skype, JD.ID, Shopee, dan Zoom. Penerapan pajak digital ini diharapkan untuk mendongkrak penerimaan pajak dikala pandemi Covid19 ini. 
Kedua, Pajak Bandara Bebas untuk Memulihkan Sektor Pariwisata. Pemeintah membuat peraturan dengan menghapus biaya yaitu biaya Pelayanan Jasa Penumpang Pesawat Udara atau airport tax di 13 bandara untuk mendorong pemulihan sektor pariwisata dan penerbangan. Airport tax mempunyai arti salah satu dari jenis pajak yang dibebankan atau dikenakan kepada penumpang ketika mereka berada di Bandara. Airport tax dikenakan dan dimasukkan langsung kedalam harga tiket yang dijual oleh maskapai. Dengan dibebaskan airport tax akan menurunkan harga tiket pesawat penumpang sehingga diharapkan dapat membangkitkan pertumbuhan semua sektor usaha penyokong pariwisata, terutama UMKM.

Ketiga, pemberian insentif pajak. Pembangunan ekonomi dapat dilakukan dengan memberikan insentif pajak, fasilitas pembebasan, menurunkan tarif pajak, dan fasilitas lainnya yang mengurangi beban pajak masyarakat. Upaya tersebut dinilai sebagai cara dari pemerintah untuk mendorong pertumbuhan ekonomi masyarakat. Salah satu upaya yang diberikan dibidang perpajakan adalah pemberian insentif PPh kepada pelaku usaha kecil dan menengah, berupa PPh Final para pelaku UMKM ditanggung oleh pemerintah. Dalam rangka mendorong ekonomi dan keberlanjutan UMKM di Indonesia, pemerintah menanggung $\mathrm{PPh}$ final UMKM sebesar tarif yaitu $0,5 \%$ dari omzet atau penghasilan bruto. Insentif ini diberikan dalam rangka melaksanakan fungsi pemerintah sebagai pembangun ekonomi yang berkelanjutan. Wajib pajak UMKM tidak perlu lapor dengan surat keterangan Peraturan Pemerintah Nomor 23 tahun 2018, sebagai gantinya hanya perlu lapor realisasi usahanya melalui pajak.go.id sebagai monitoring dari pemerintah.

Upaya pemberian insentif yang kedua adalah pembebasan PPh Pasal 22 impor. Langkah ini ditempuh oleh pemerintah guna mendorong para pelaku usaha dapat bersaing didunia internasional. Dengan adanya pembebasan salah satu pajak yaitu PPh Pasal 22 impor, diharapkan bisnis dalam negeri akan lebih ringan cost dalam produksi barang dan jasa. Realsiasi pemanfaatan insentif adalah sebesar 7,33 triliun rupiah.

Insentif yang ketiga adalah adanya diskon angsuran PPh Pasal 25 sebesar $50 \%$. Insentif diskon angsuran pajak ini dimanfaatkan dengan jumlah yang terbesar diantara insentif yang lain. Realisasi insentif diskon angsuran adlaah $\mathrm{Rp} 10,19$ triliun rupiah. Angka tersebut dikatakan terbesar karena nebyumbang $71 \%$ dari alokasi 14,4 triliun rupianh. Diskon yang diberikan juga mengalami kenaikan dari $30 \%$ menjadi $50 \%$. Hal ini diberikan oleh pemerintah agar wajib pajak tidak terbebani di tengah pandemi ini.

Restitusi salah satu pajak yaitu Pajak Pertambahan Nilai (PPN) akan dipercepat prosesnya oleh pemerintah. Hal ini berkaitan dengan berjalannya roda bisnis usaha pelaku usaha di Indonesia. Insentif restitusi ini 3,16 triliun. Pemerintah mengharapkan bahwa dengan insentif ini keuangan para pelaku bisnis dapat stabil, sehingga bisnis akan tetap berjalan, produksi barang dan jasa dapat terus berlanjut, minimnya karyawan yang akan dirumahkan. 


\section{E. SIMPULAN}

Penerimaan pajak di Indonesia yang selama lima tahun belum mampu mencapai target. Di tahun 2020 di bulan September penerimaan pajak di Indonesia adalah 720,62 triliun rupiah dari target 1.198,82 triliun rupiah. Data kepatuhan pajak yang diukur melalui pelaporan SPT Tahunan juga masih jauh dari target yang seharusnya. Di tahun 2020 Wajib Pajak terdaftar sekitar 19 juta wajib pajak, dan yang sudah melapor adalah 11,5 juta wajib pajak. Angka tersebut jika dipresentasekan adalah sebesar 60,34\% jumlah wajib pajak yang taat pajak. Angka tersebut tergolong rendah dan kepatuhan wajib pajak dikategorikan rendah. Tax ratio yang selama 5 tahun terakhir cenderung diangka yang sama dan tidak megalami peningkatan. Hal ini dapat digambarkan bahwa kinerja DJP dalam penerimaan pajak harus ditingkatkan dan membutuhkan strategi dalam mengoptimalkan penerimaan pajaknya.

Beberapa strategi DJP dalam optimalsiasi penerimaan pajak adalah sebagai berikut Pertama, Ekstensifikasi pemerintah harus segera menerapkan pajak digital di era pandemi Covid-19 ini. Kedua, Pajak Bandara Bebas untuk Memulihkan Sektor Pariwisata. Ketiga, pemberian insentif pajak. Beberapa strategi yang diharapkan dapat meningkatkan penerimaan pajak ini harus segera dijalankan sehingga penerimaan pajak negara dapat bertambah dan dapat menstabilkan perekonomian. Pelaksanaan startegi perpajakan ini membutuhkan keterlibatan dan partisipasi masyarakat sebagai pendukung pemerintah sebagai warga negara yang baik. 


\section{DAFTAR PUSTAKA}

Cheisviyanny, C. (2020). Memulihkan Penerimaan Pajak Pasca Pandemi Covid-19. In JURNAL PAJAK INDONESIA (Indonesian Tax Journal) (Vol. 4, Issue 1). https://jurnal.pknstan.ac.id/index.php/JPI/article/view/821

Data, K. (2020). Utang Luar Negeri Indonesia Naik Jadi Rp 5.843 T per Juni 2020 I Databoks. KataData.Com. https://databoks.katadata.co.id/datapublish/2020/08/14/utang-luar-negeriindonesia-naik-jadi-rp-5843-t-per-juni-2020

DDTC. (2020a). Rasio Kepatuhan Formal WP Rendah, DJP Masih Berupaya Capai $80 \%$. DDTC.Com. https://news.ddtc.co.id/rasio-kepatuhan-formalwp-rendah-djp-masih-berupaya-capai-80-23799

DDTC. (2020b). Tren Target dan Realisasi Penerimaan Pajak Satu Dekade Terakhir. DDTC.Com. https://news.ddtc.co.id/tren-target-dan-realisasipenerimaan-pajak-satu-dekade-terakhir-18772

Desideria, E. \& N. (2019). Faktor-Faktor Yang Mempengaruhi Penerimaan Pajak Dari Wajib Pajak Badan Tahun 2016-2017. Jurnal Multiparadigma AKuntansi, I(2), 355-363.

Hafidz Al Faruqi. (2016). Analisis strategi optimalisasi pendapatan asli daerah melalui peningkatan penerimaan pajak hiburan di Kabupaten Banyuwangi $=$ Analysis of local revenue optimization strategies through an increase of tax entertainment revenues in Banyuwangi [Universitas Indonesia]. http://lib.ui.ac.id/detail?id=20430130\&lokasi=lokal

Kamilia, G., Ilmu, F., Dan, S., Politik, I., Administrasi, D. I., Studi, P., \& Negara, A. (2014). UNIVERSITAS INDONESIA IMPLEMENTASI KEBIJAKAN PAJAK ROKOK ( STUDI PADA AKTIVITAS PEMERINTAH PUSAT DALAM MEMPERSIAPKAN PEMUNGUTAN PAJAK ROKOK ) UNIVERSITAS INDONESIA IMPLEMENTASI KEBIJAKAN PAJAK ROKOK ( STUDI PADA AKTIVITAS PEMERINTAH PUSAT DALAM MEMPERSIAP [Universitas Indonesia]. http://lib.ui.ac.id/detail?id=20385968\&lokasi=lokal

Kommer, A. M. dan V. van. (2011). Handbook for Tax Administrations: Organizational Structure and Management of Tax Administrations. The Netherlands.

Lasfika, Y. (2020). Analisis kinerja pegawai Sekretariat Direktorat Jenderal Imigrasi $=$ Analysis of employees performance at Sekretariat Direktorat Jenderal Imigrasi / Yudhitia Lasfika [Universitas Indonesia]. In Universitas Indonesia. http://lib.ui.ac.id/detail?id=20413471\&lokasi=lokal

Pajak, D. J. (2018). Laporan Kinerja Tahun 2018 | Direktorat Jenderal Pajak. Pajak.Go.Id. https://www.pajak.go.id/id/laporan-kinerja-tahun-2018

Putra, I. (2020). Tantangan Berat DJP untuk Dongkrak Penerimaan Pajak di 20202021 merdeka.com.

Merdeka.Com. 
https://www.merdeka.com/uang/tantangan-berat-djp-untuk-dongkrakpenerimaan-pajak-di-2020-2021.html

Rahayu, N. (2010). Regulatory Evaluation of Foreign Investment Tax Avoidance Practices. Jurnal Akuntansi Dan Keuangan Indonesia, 7(1), 61-78.

Rosdiana Haula, E. S. R. (2012). Pengantar ilmu Pajak, Kebijakan dan Implementasi di Indonesia. PT Raja Grafindo Persada.

Triadi, R. (2013). Analisis kinerja pegawai Badan Kependudukan dan Keluarga Berencana Nasional Pusat $=$ Analysis of employees performance at National Population and Family Planning Board [Universitas Indonesia]. In Universitas Indonesia. http://lib.ui.ac.id/detail?id=20330622\&lokasi=lokal\#parentHorizontalTab2

Valensky, N. (2018). Analisis mewujudkan cooperative compliance pada industri e-commerce sebagai upaya optimalisasi penerimaan pajak penghasilan $=$ Analysis to achieve cooperative compliance in e-commerce industry as an effort of income tax optimalization [Universitas Indonesia]. In Universitas Indonesia. http://lib.ui.ac.id/detail?id=20472855\&lokasi=lokal 